\title{
Sistem Informasi Pemesanan dan Pembayaran Kamar pada Apple Hotel Perdagangan Kabupaten Simalungun
}

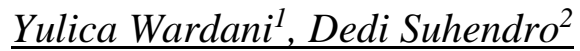 \\ Komputerisasi Akuntansi AMIK Tunas Bangsa Pematangsiantar \\ Jl. Jend. Sudirman Blok A No. 1,2,3 Pematangsiantar, Indonesia \\ E-mail:Yulica0823@gmail.com ${ }^{1}$,dedi.su@amiktunasbangsa.ac.id ${ }^{2}$
}

\begin{abstract}
Apple Hotel as one of the modern hotels in the city of Perdagangan Simalungun Regency is a developing hotel and continuously striving to improve services and hotel quality standards from various sides, including the use of information technology. Booking a room (check in) at the Apple Hotel is still less effective, because recording is still conventional by recording into a ledger, so it takes a long time to find an empty room, calculating the cost of checking out and making reports that are often late. The purpose of this research is to design a computerized dynamic information system that produces effective and accurate hotel room bookings and payments that will later be used at Apple Hotel in the Perdagangan Simalungun Regency. The author builds an information system using Visual Studio 2010 and MySQL. The system development methodology uses the prototype method by planning, analyzing and designing as well as the system making phase (coding). The results and conclusions of the ordering and payment information system at Apple Hotel in the Perdagangan Simalungun Regency, inputting, searching, ordering and payment will be easier and know the order and payment reports.
\end{abstract}

Keywords : Apple Hotels, MySQL, information systems, visual basic

\begin{abstract}
Abstrak
Apple Hotel sebagai salah satu hotel modern di kota Perdagangan Kabupaten Simalungun merupakan hotel sedang berkembang dan terus berupaya untuk meningkatkan layanan serta standar kualitas hotel dari berbagai sisi, antara lain pemanfaatan teknologi informasi. Pemesanan kamar (check in) di Apple Hotel masih kurang efektif, karena pencatatan masih secara konvensional dengan mencatat kedalam buku besar, sehingga butuh waktu lama untuk mencari kamar yang kosong, perhitungan biaya check out dan pembuatan laporan yang sering terlambat. Tujuan dilakukan penelitian ini untuk merancang sistem informasi yang bersifat dinamis secara terkomputerisasi menghasilkan pemesanan dan pembayaran kamar hotel yang efektif dan akurat yang nantinya akan digunakan di Apple Hotel Perdagangan Kabupaten Simalungun. Penulis membangun sistem informasi menggunakan Visual Studio 2010 dan MySQL. Pengembangan sistem menggunakan metode prototype dengan melakukan perencanaan, analisa dan perancangan serta tahap pembuatan sistem (coding). Hasil dan kesimpulan dari sistem informasi pemesanan dan pembayaran pada Apple Hotel Perdagangan Kabupaten Simalungun, penginputan, pencarian, pemesanan dan pembayaran akan lebih mudah serta mengetahui laporan pemesanan dan pembayaran.
\end{abstract}

Kata kunci : Apple Hotel, MySQL, Sistem Informasi, Visual Basic

\section{Pendahuluan}

Hotel termasuk kedalam jenis akomodasi yang mempergunakan sebagian atau keseluruhan bagian untuk jasa pelayanan penginapan, penyedia makanan dan minuman serta jasa lainnya bagi masyarakat umum yang dikelola secara komersil. Perusahaan atau badan usaha akomodasi yang menyediakan pelayanan jasa penginapan, penyedia makanan dan minuman serta fasilitas jasa lainnya bagi tamu yang datang, baik mereka yang bermalam di hotel tersebut ataupun mereka yang hanya menggunakan fasilitas tertentu yang dimiliki hotel itu atau bisa dibilang semua pelayanan itu diperuntukkan bagi masyarakat umum. Hotel 
merupakan jenis akomodasi yang menyediakan pelayanan, penginapan, akomodasi, makanan dan minuman, disediakan bagi setiap orang, dikelola secara komersial dengan tujuan mencari keuntungan [1].

Fungsi hotel bukan hanya sebagai tempat menginap untuk tujuan wisata, namun juga untuk tujuan lain, seperti menjalankan kegiatan bisnis, mengadakan seminar, atau sekedar untuk mendapatkan ketenangan [2]. Selain dari kegunaannya, fungsi hotel juga bisa dilihat dari sisi para penerima manfaatnya, yaitu pemilik, karyawan, tamu, dan pemerintah. Bagi pemiliknya, hotel untuk mendapatkan keuntungan finansial serta menyelamatkan dan mengamankan modal yang sudah dikeluarkan untuk membangunnya. Bagi karyawan, hotel tempat mencari nafkah untuk mendapatkan penghasilan demi pemenuhan kebutuhan hidup yang layak bagi diri dan keluarganya, juga tempat menambah kemampuan dan pengalaman. Bagi para tamu, hotel berfungsi sebagai tempat menginap sementara yang diharapkan bisa memberikan pelayanan yang nyaman, aman, dan memuaskan. Bagi pemerintah, keberadaan hotel memiliki fungsi penting untuk menyerap tenaga kerja setempat, menambah pendapatan daerah; dan membantu mempromosikan objek wisata setempat.

Salah satu hotel modern di kawasan Perdagangan Kabupaten Simalungun adalah Apple Hotel yang merupakan hotel sedang berkembang dan terus berupaya untuk meningkatkan layanan serta standar kualitas hotel dari berbagai sisi antara lain sisi pemanfaatan teknologi informasi. Apple Hotel didirikan pada tanggal 17 Juli 2009 di kota Perdagangan Kabupaten. Selama ini, sistem pemesanan kamar atau check in yang ada di Apple Hotel masih kurang efektif, karena pencatatan masih secara konvensional dengan mencatat kedalam buku besar, sehingga butuh waktu lama untuk mencari kamar yang kosong, perhitungan biaya check out dan pembuatan laporan yang sering terlambat.

Pada beberapa penelitian juga menemukan permasalahan yang sama. Reservasi yang dilakukan melalui telepon atau datang langsung ke hotel tidak efektif karena akan mengeluarkan waktu yang lebih banyak hanya untuk sebuah proses reservasi dan rentan akan terjadi kesalahan [3], menyulitkan bagi pelanggan yang ada diluar kota untuk memesan kamar secara cepat [4]. Penggunaan Sistem Informasi terkomputerisasi mampu mengatasi permasalahan sebagai mana yang di nyatakan pada penelitian sebelumnya, membantu petugas dalam pencatatan sewa hotel dan penggunaan fasilitas lainnya [5], dapat memberi gambaran pada pihak hotel untuk mengetahui data pemesan kamar dan dapat menyelesaikan penghitungan pembayaran sewa kamar dengan cepat dan tepat [6], mempermudah transaksi check in, check out, bill check out, sehingga dalam mengelola data tamu menjadi lebih mudah, cepat dan efisien [7].

Berdasarkan permasalahan tersebut, maka penulis membangun sistem informasi pada pemesanan dan pembayaran kamar hotel pada Apple Hotel Perdagangan Kabupaten Simalungun sebagai solusi atas permasalahan pemesana kamar pada hotel tersebut.

\section{Metodologi \\ 2.1 Perencanaan}

Metode yang dilakukan dengan cara mengadakan wawancara langsung dengan pihak Apple Hotel Perdagangan Kabupaten Simalungun, dalam hal ini manajemen Apple Hotel. Kegiatan yang dilakukan adalah melakukan wawancara tentang masalah yang sering dihadapi dalam pemesanan kamar dan pembayaran kamar. Observasi dilakukan secara langsung proses pemesanan dan pembayaran kamar pada Apple Hotel Perdagangan Kabupaten Simalungun. Selain untuk mengindentifikasi masalah dan kebutuhan pengguna, wawancara dan observasi juga menghasilkan data.

\subsection{Analisa dan Perancangan}

Pada tahap analisis ini dilakukan identifikasi dan penyebab masalah. selanjutnya analisa terhadap sistem yang sedang dijalankan dan analisa sistem usulan akan dibangun. Analisa yang dilakukan adalah proses sistem yang ada saat ini di Apple Hotel Perdagangan Kabupaten Simalungun. Hasil analisa akan digunakan untuk dasar dalam merancang dan membangun sistem. Sedangkan pada tahap perancangan dilakukan rancangan-rancangan/desain terhadap sistem. Rancangan sistem yang dibangun nantinya disesuaikan dengan kebutuhan dari proses bisnis Apple Hotel Perdagangan Kabupaten Simalungun. 


\subsection{Tahap Pembuatan Sistem (coding)}

Tahapan ini merupakan fase pembuatan sistem (coding). Metodologi pengembangan sistem menggunakan metode prototype. Prototype itu sendiri merupakan suatu metode dalam pengembangan sistem yang menggunakan pendekatan untuk membuat suatu program dengan cepat dan bertahap sehingga dapat dievaluasi oleh pemakai. Selain itu, prototyping membantu Anda dan pemangku kepentingan lainnya untuk lebih memahami apa yang akan dibangun ketika persyaratan tidak jelas [8]. Tools yang digunakan dalam membuat aplikasi ini menggunakan Pemrograman Visual Studio 2010 dan database MySQL.

\section{Hasil dan Pembahasan}

Sistem informasi pemesanan dan pembayaran kamar hotel pada Apple Hotel Perdagangan Kabupaten Simalungun dapat didefenisikan sebagai penggambaran, perencanaan dan pembuatan proses serta data yang diperlukan oleh sistem yang dibangun.Permodelannya menggunakan DFD untuk menggambarkan proses bisnis dan data yang mengalir di dalamnya [9].

\subsection{Rancangan Proses}

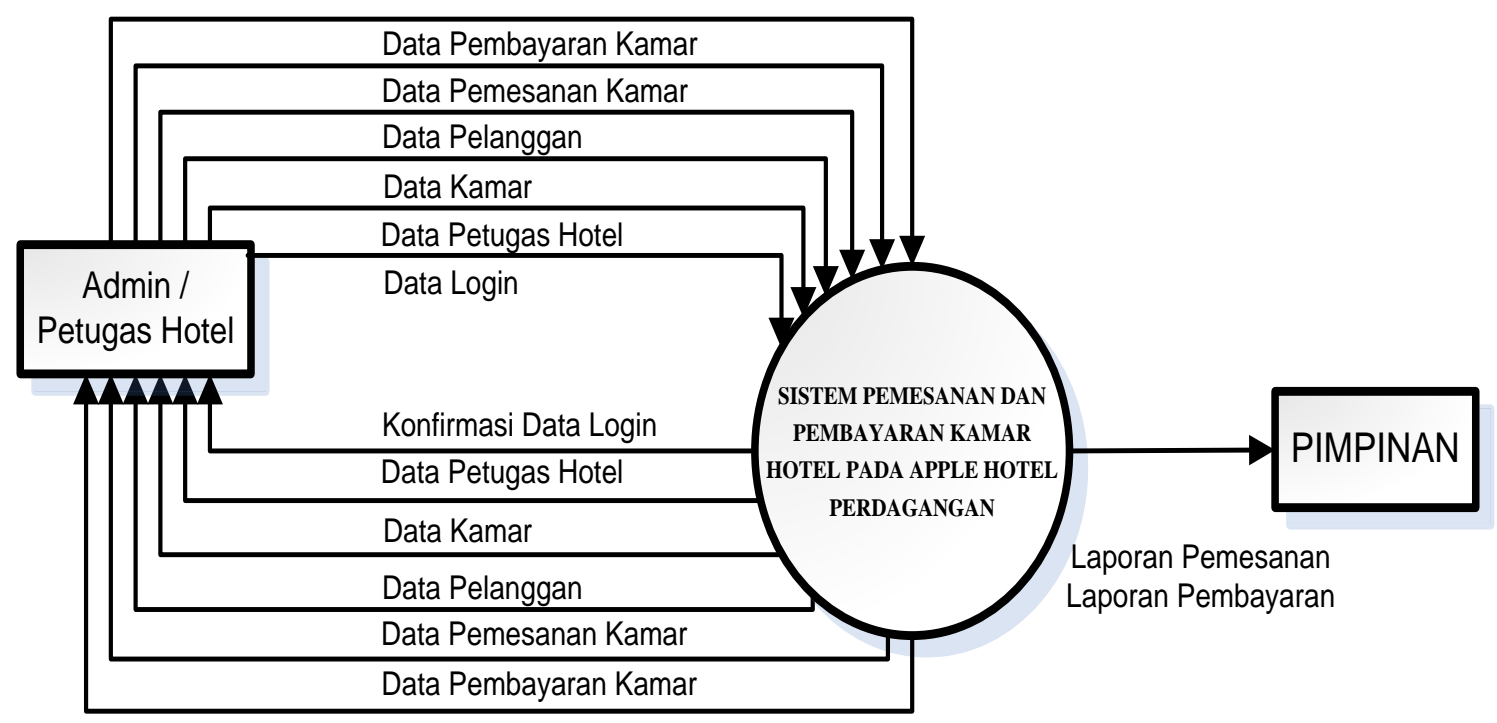

Gambar 1. Rancangan DFD Level 0

Pada DFD Level 1 terdiri dari 6 proses yang dilakukan yaitu : Proses data admin, proses data petugas hotel, proses data kamar, proses data pelanggan, proses data pemesanan, proses data pembayaran dan laporan pemesanan dan pembayaran. Perancangan DFD Level 1 dapat dilihat pada gambar 2 sebagai berikut : 


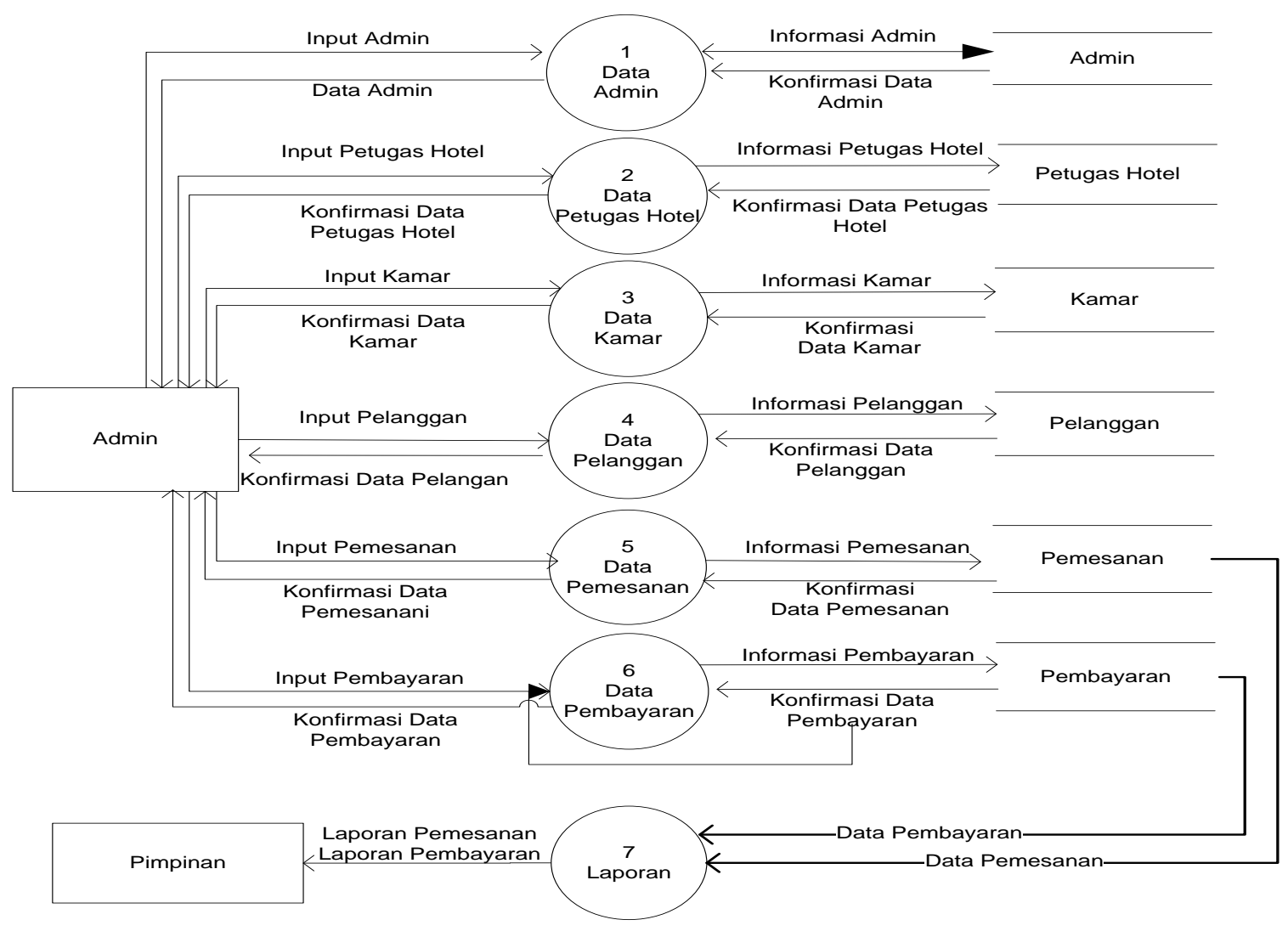

Gambar 2. Rancangan DFD Level 1

\subsection{Rancangan Basis Data}

Relasi Antar Tabel (RAT) yang berguna sebagai gambaran hubungan antara tabel dimana tabel yang mempunyai relasi dapat saling memiliki kaitan. Adapun Relasi Antar Tabel (RAT) pada sistem informasi pemesanan dan pembayaran kamar hotel pada Apple Hotel Perdagangan Kabupaten Simalungun dapat dilihat pada gambar 3 berikut :

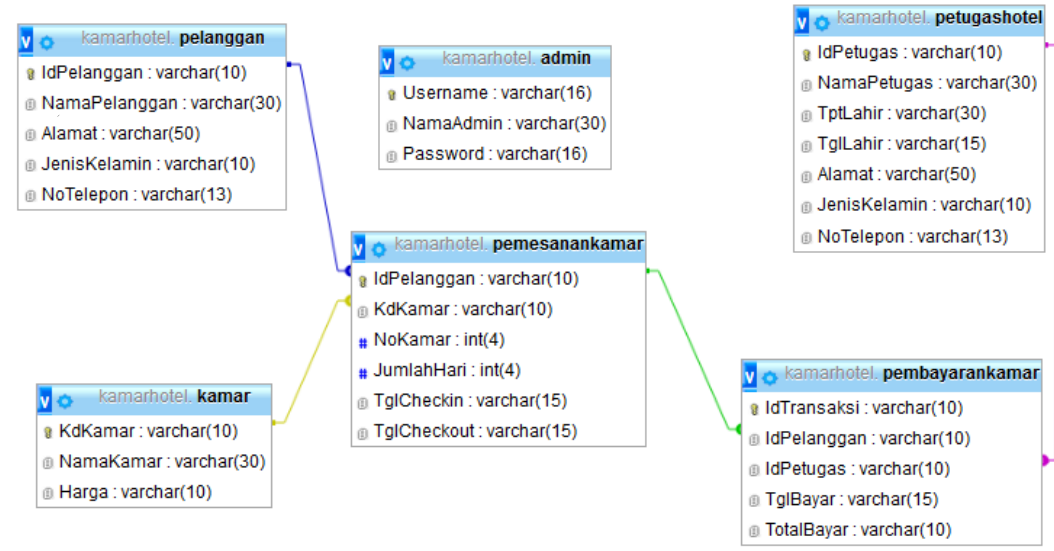

Gambar 3. Relasi Antar Tabel (RAT) 
ERD menunjukkan hubungan logis dan interaksi antara entitas sistem. ERD menyediakan tampilan keseluruhan sistem dan cetak biru untuk membuat struktur data fisik [10]. Berikut diagram ERD yang dirancang.

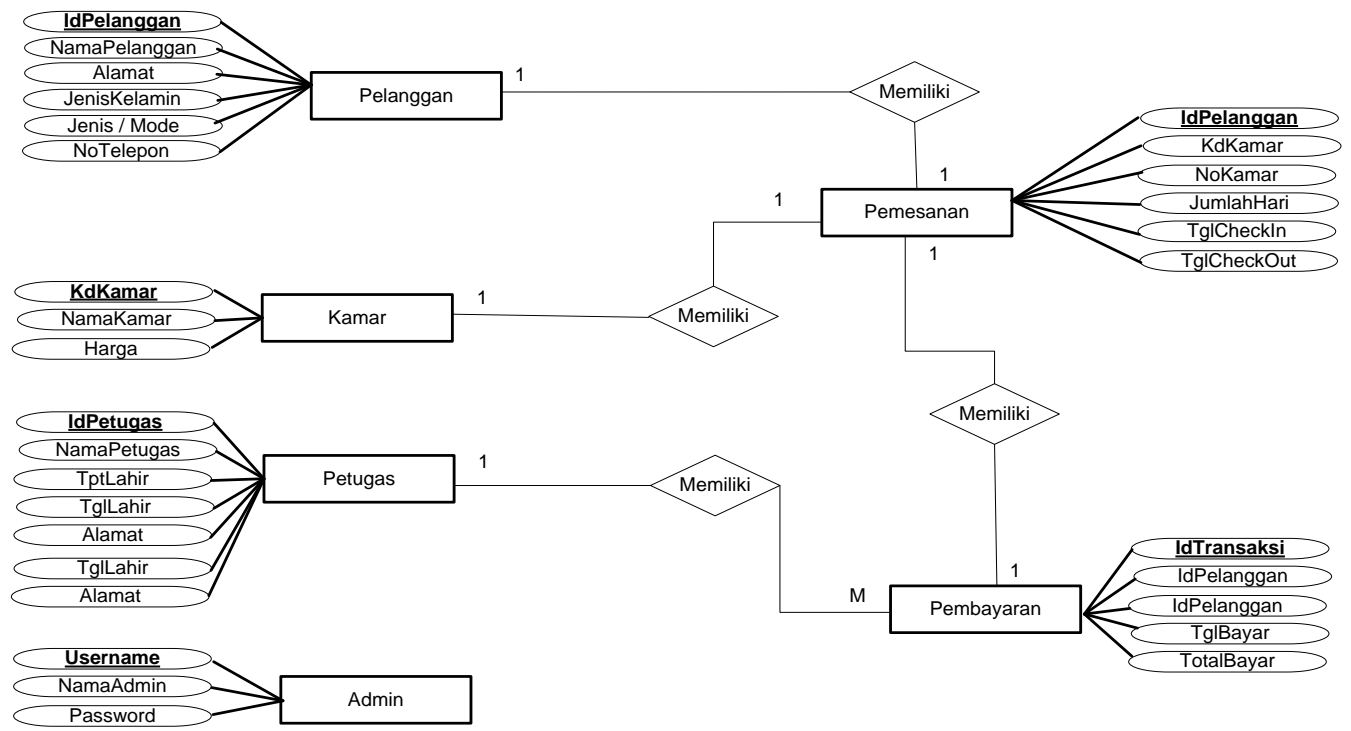

Gambar 4. ERD (EntityRelationship Diagram)

\subsection{Desain Antar Muka}

Desain antar muka dari sistem informasi yang dirancang ditunjukkan sbagai berikut :

1. Menu Login

Sebelum masuk ke menu utama dari sistem informasi pemesanan dan pembayaran kamar hotel pada Apple Hotel Perdagangan Kabupaten Simalungun ini pertama adanya form login admin yang berfungsi untuk keamanan sistem seperti pada gambar 5 .

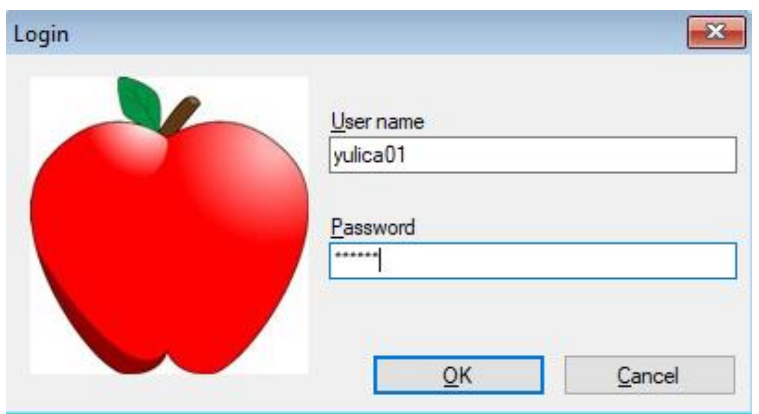

Gambar 5. Form Login

2. Menu Utama

Adapun struktur menu-menu yang disiapkan dalam penelitian ini adalah:

a. Data Admin

Pada proses mengelolah data Admin, user memasukkan data Admin yang akan diteruskan ke proses mengelolah data Admin. Selanjutnya, disimpan pada data storage tabel Admin. Setelah data Admin tersimpan di dalam data storage tabel Admin, maka tabel Admin tersebut akan diinformasikan kepada Admin.

b. Proses mengolah data Petugas Hotel

Pada proses mengelolah data Petugas Hotel, user memasukkan data Petugas Hotel yang akan diteruskan ke proses mengelolah data Petugas Hotel. Selanjutnya, disimpan pada data storage tabel Petugas Hotel. Setelah data Petugas Hotel tersimpan di dalam data storage tabel Petugas Hotel, maka tabel Petugas Hotel tersebut akan diinformasikan kepada Admin. 
c. Proses mengelolah data Kamar

Pada proses mengelolah data Kamar, user memasukkan data Kamar yang akan diteruskan ke proses mengelolah data Kamar. Selanjutnya, disimpan pada data storage table Kamar. Setelah data Kamar tersimpan di dalam data storage tabel Kamar, maka table Kamar tersebut akan diinformasikan kepada Admin.

d. Proses mengelolah data Pelanggan

Pada proses mengelolah data Pelanggan, user memasukkan data Pelanggan yang akan diteruskan ke proses mengelolah data Pelanggan. Selanjutnya, disimpan pada data storage tabel Pelanggan. Setelah data Pelanggan tersimpan di dalam data storage tabel Pelanggan, maka tabel Pelanggan tersebut akan diinformasikan kepada Admin.

e. Proses mengelolah data Pemesanan

Pada proses mengelolah data Pemesanan, user memasukkan data Pemesanan yang akan diteruskan ke proses mengelolah data Pemesanan. Selanjutnya, disimpan pada data storage tabel Pemesanan. Setelah data Pemesanan tersimpan di dalam data storage tabel Pemesanan, maka tabel Pemesanan tersebut akan diinformasikan kepada Admin.

f. Proses mengelolah data Pembayaran

Pada proses mengelolah data Pembayaran, user memasukkan data Pembayaran yang akan diteruskan ke proses mengelolah data Pembayaran. Selanjutnya, disimpan pada data storage tabel Pembayaran. Setelah data Pembayaran tersimpan di dalam data storage tabel Pembayaran, maka tabel Pembayaran tersebut akan diinformasikan kepada Admin.

g. Proses mengelolah data Laporan Pemesanan dan Penjualan

Pada proses ini hasil dari seluruh data yang sudah diterima oleh admin akan dicetak dalam bentuk laporan pemesanan dan pembayaran lalu akan diberikan kepada Pimpinan.

3. Masukan (Input) Sistem

Masukan (Input) sistem ini digunakan untuk memasukkan data ke dalam sistem, Adapun form-form untuk masukan (Input) sistem adalah:

Form Data Admin dapat dijalankan dengan memilih menu pada form utama, kemudian pilih Admin, maka form Data Admin akan tampil. Tampilan form Data Admin dapat dilihat pada gambar 11, berikut :



Form data Petugas Hotel dapat dijalankan dengan memilih menu pada form utama, kemudian pilih data Petugas Hotel, maka form data Petugas Hotel akan tampil. Tampilan form data Petugas Hotel dapat dilihat pada gambar 12, berikut : 


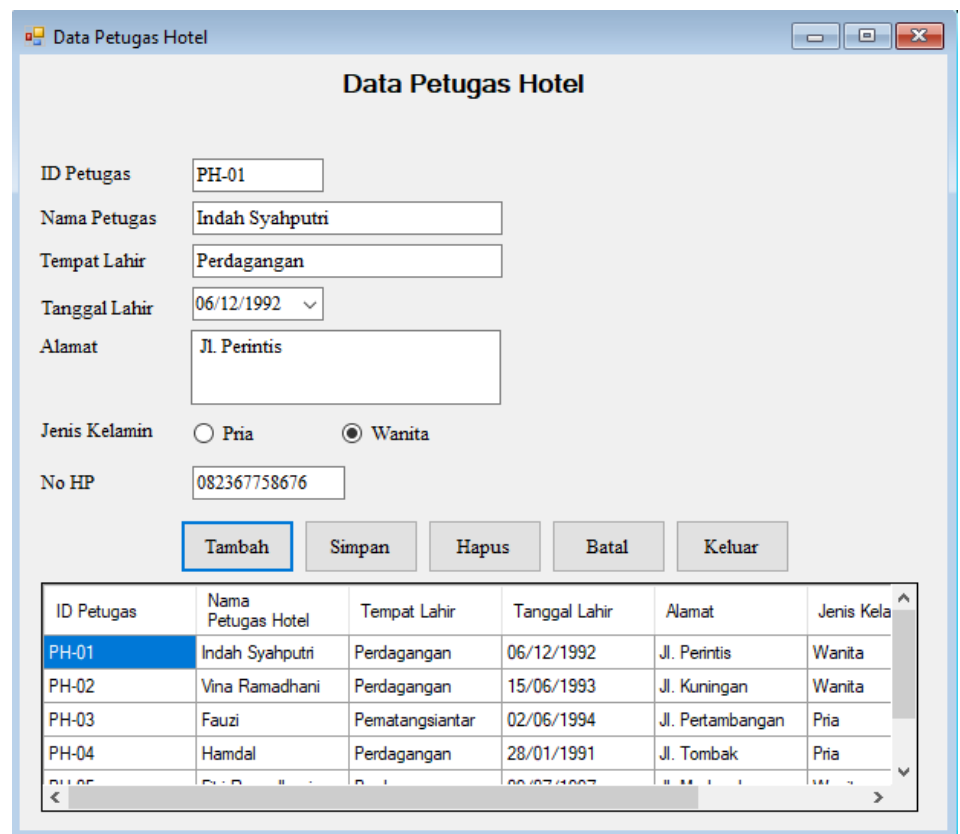

Gambar 12. Tampilan form Data Petugas Hotel

Form Data Kamar dapat dijalankan dengan memilih menu pada form utama, kemudian pilih Data Kamar, maka form Data Kamar akan tampil. Tampilan form Data Kamar dapat dilihat pada gambar 13, berikut :

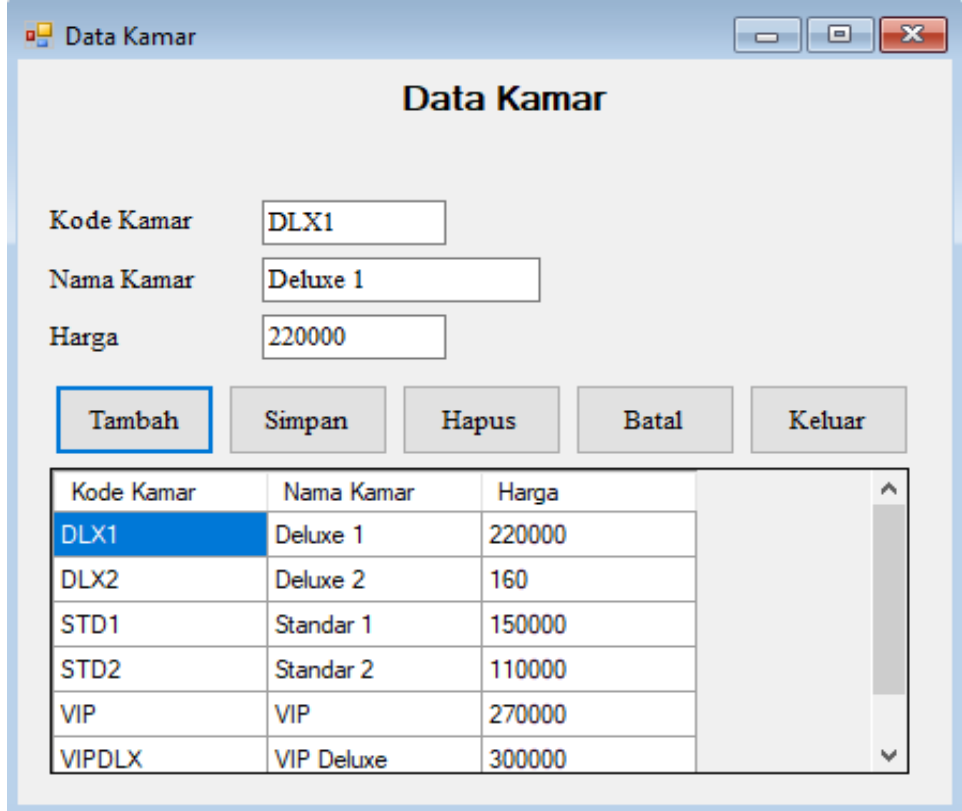

Gambar 13. Tampilan form Data Kamar

Form Data Pelanggan dapat dijalankan dengan memilih menu pada form utama, kemudian pilih Data Pelanggan, maka form Data Pelanggan akan tampil. Tampilan form Data Pelanggan dapat dilihat pada gambar 14, berikut : 


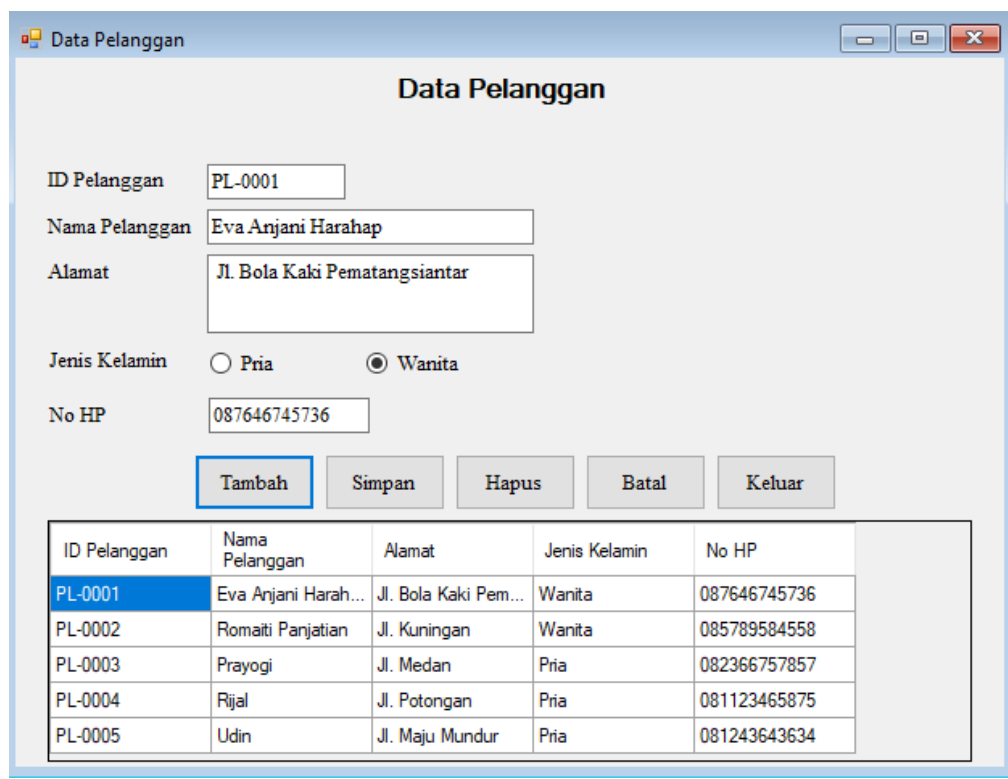

Gambar 14. Tampilan form Data Pelanggan

4. Form Transaksi

Form data pemesanan kamar dapat dijalankan dengan memilih menu pada form utama, kemudian pilih data pemesanan kamar, maka form data pemesanan kamar akan tampil. Tampilan form data pemesanan kamar dapat dilihat pada gambar 15, berikut :



Gambar 15. Tampilan form Data Pemesanan Kamar

Form data pembayaran kamar dapat dijalankan dengan memilih menu pada form utama, kemudian pilih data pembayaran kamar, maka form data pembayaran kamar akan tampil. Tampilan form data pembayaran kamar dapat dilihat pada gambar 16, berikut : 


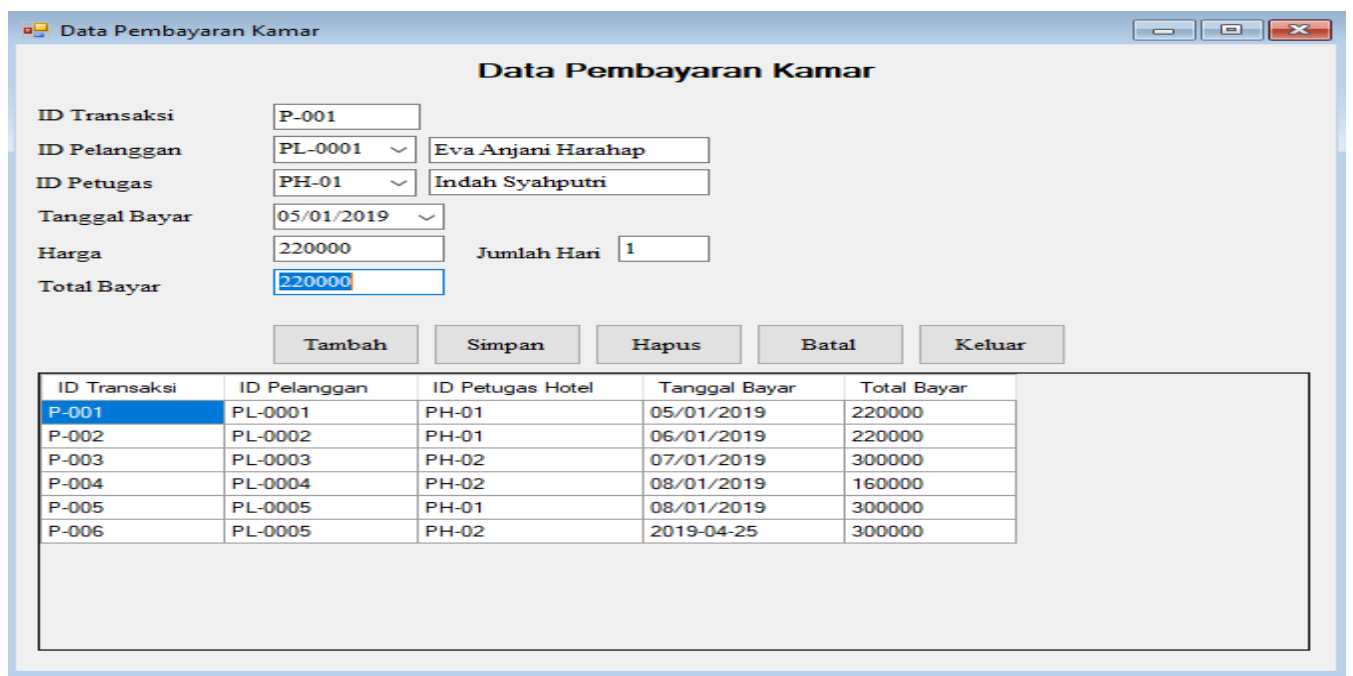

Gambar 16. Tampilan form Data Pembayaran Kamar

5. Keluaran (Output) Sistem

Keluaran (Output) sistem berfungsi sebagai pencarian dan laporan yang dapat dicetak dari data yang telah dipilih. Form Laporan pembayaran kamar pada Apple Hotel Perdagangan Kabupaten Simalungun dijalankan dengan memilih menu pada form utama, kemudian pilih Cetak Laporan Pembayaran, maka form Laporan Pembayaran dapat dilihat pada gambar 17 dan gambar 18, berikut:

\begin{tabular}{|c|c|c|c|c|c|c|c|c|}
\hline \multicolumn{7}{|c|}{$\square$ Laporan Pembayaran } & \multicolumn{2}{|c|}{ 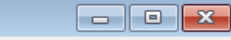 } \\
\hline \multicolumn{9}{|c|}{ Data Laporan Pembayaran Kamar } \\
\hline Cari Berdasarkar & $\mathrm{n}$ : $\mathbb{D \text { Transaksi }}$ & $v$ & \multicolumn{3}{|c|}{ Kriteria } & & & \\
\hline $\begin{array}{l}\text { ID } \\
\text { Transaksi }\end{array}$ & $\begin{array}{l}\text { Nama } \\
\text { Pelanggan }\end{array}$ & $\begin{array}{l}\text { Nama } \\
\text { Kamar }\end{array}$ & Harga & $\begin{array}{l}\text { Jumlah } \\
\text { Han }\end{array}$ & $\begin{array}{l}\text { Tanggal } \\
\text { Checkin }\end{array}$ & $\begin{array}{l}\text { Tanggal } \\
\text { Checkout }\end{array}$ & & \\
\hline P-001 & Eva Anjani Harahap & Deluxe 1 & 220000 & 1 & 05/01/2019 & 06/01/2019 & & \\
\hline P-002 & Romatit Panjatian & Standar 2 & 110000 & 2 & 05/01/2019 & 07/01/2019 & & \\
\hline P-003 & Prayogi & VIP Deluxe & 300000 & 1 & 07/01/2019 & 08/01/2019 & & \\
\hline P-004 & Rijal & Deluxe 2 & 160 & 1 & 2019-01-08 & 2019-01-09 & & \\
\hline P-005 & Udin & Standar 1 & 150000 & 2 & 08/01/2019 & 10/01/2019 & & \\
\hline \multirow[t]{2}{*}{ P-006 } & Udin & Standar 1 & 150000 & 2 & 08/01/2019 & 10/01/2019 & & \\
\hline & & & & & & & Cetak & Keluar \\
\hline
\end{tabular}

Gambar 17. Tampilan Form Laporan Pembayaran Kamar 


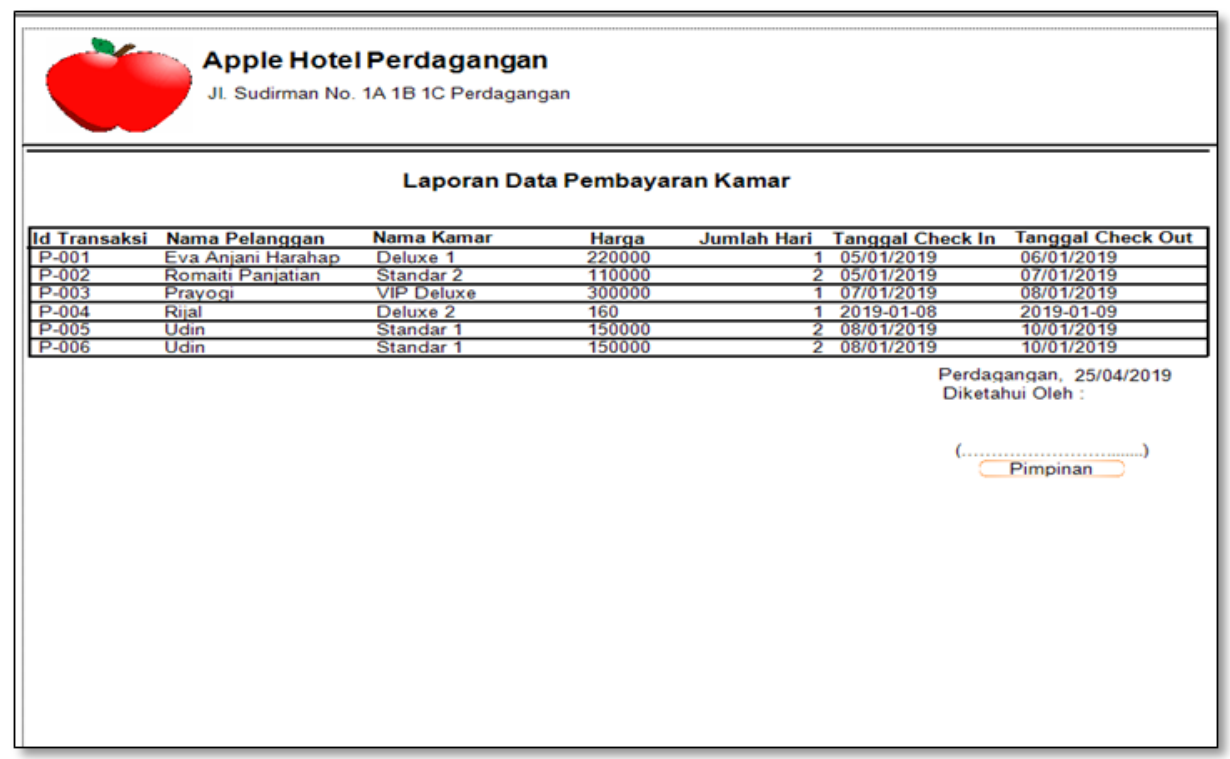

Gambar 18. Tampilan Cetak Laporan Pembayaran

\section{Kesimpulan}

Berdasarkan penelitian yang penulis laksanakan pada Apple Hotel Perdagangan Kabupaten Simalungun, sistem informasi ini bersifat dinamis secara terkomputerisasi mengolah pemesanan dan pembayaran kamar hotel yang efektif dan akurat, menyimpan data-data secara terperinci sehingga proses penginputan dan proses pencarian data pemesanan dan pembayaran akan lebih mudah.

\section{Daftar Rujukan}

[1] H. Krestanto, "Strategi Dan Usaha Reservasi Untuk Meningkatkan Tingkat Hunian Di Grand Orchid Hotel Yogyakarta," J. Media Wisata, vol. 17, no. 1, pp. 1-8, 2019.

[2] S. Hidayat, "Peranan Hotel Lombok Raya terhadap Masyarakat Sekitar dan Daya Dukungnya terhadap Kebutuhan Sektor Pariwisata di Pulau Lombok,” J. Valid, vol. 14, no. 2, pp. 1-10, 2017.

[3] A. Wirapraja, N.T. Hariyanti, G.S. Perdana, "Desai Prototyping Sistem Informasi Mnajemen Layanan Reservasi Hotel X Berbasis Web", Jurnal Eksekuti, vol. 16, no. 2, pp. 215-238, 2019.

[4] I. Maita, A. Adawiyah, "Sistem Informasi Reservasi Onine Pada Guest House UIN SUSKA Riau Berbasiskan Web", Jurnal Ilmiah Rekayasa dan Manajemen Sistem Informasi, vol. 3, no. 1, pp. 85-96, 2017.

[5] N. Purwati and N. Hasan, "Perancangan Sistem Informasi Administrasi Tamu Hotel (Studi Kasus pada Hotel Ganesha Purworejo)," J. Speed - Sentra Penelit. Eng. dan Edukasi, vol. 8, no. 1, pp. 36-43, 2016.

[6] R. Damayanti, I. U. Wardati, "Perancangan Sistem Informasi Pemesanan dan Pembayaran Kamar pada Hotel Remaja Pacitan," Evolusi, vol. 4, no. 2, pp. 11-19, 2016.

[7] Fitriyanti, "Analisa dan Perancangan Sistem Informasi Reservasi Kamar Pada Bangka City Hotel Pangkalpinang Berbasis Web, KNSI, pp. 1084-1089, 2018.

[8] R. S. Pressman, Software Engineering : A Practitioner's Approach, 7 ed., McGrawHill, 2010.

[9] A. Dennis, B. H. Wixom, R. M. Roth, System Analysis and Design : Fifth Edition, John Wiley \& Sons, 2012.

[10] G. B. Shelly, H. J. Rosenblatt, Systems Analysis and Design : Ninth Edition, Shelly Cashman Series, 2012. 